\title{
Effects of the Santorini (Thera) eruption on manganese behavior in Holocene sediments of the eastern Mediterranean
}

\author{
Anja Reitz ${ }^{\mathrm{a}, *}$, John Thomson ${ }^{\mathrm{b}}$, Gert J. de Lange ${ }^{\mathrm{a}}$, Darryl R.H. Green ${ }^{\mathrm{b}}$, \\ Caroline P. Slomp ${ }^{\mathrm{a}}$, A. Catalina Gebhardt ${ }^{\mathrm{c}}$ \\ a Department of Earth Sciences-Geochemistry, Faculty of Geosciences, Utrecht, University, Budapestlaan 4, 3584 CD Utrecht, The Netherlands \\ b Southampton Oceanography Centre, Empress Dock, Southampton SO14 3ZH, United Kingdom \\ ${ }^{c}$ AWI, Alfred Wegener Institute Foundation for Polar and Marine Research, Columbusstrasse, 27568 Bremerhaven, Germany
}

Received 16 April 2005; received in revised form 1 August 2005; accepted 21 October 2005

Available online 1 December 2005

Editor: E. Boyle

\begin{abstract}
The explosive eruption on the island of Santorini in $~ 1630$ B.C. in Minoan times had a large environmental impact over the eastern Mediterranean region. It has even been suggested that the Mn-enriched layer (the "Marker Bed") above the most recent sapropel (S1) in sediments of a crestal area of the Mediterranean Ridge gained Mn from a hydrothermal source related to the Santorini eruption. Radiocarbon dating of two cores from this area sampled at high resolution demonstrate that this large Mn peak in fact pre-dates the Santorini event by $\sim 2.8 \mathrm{ky}$ and forms part of a pattern seen in Mn profiles from all over the eastern Mediterranean. This same Mn profile shape is altered in areas that experienced substantial deposits of either the tephra layer emitted by the Santorini eruption or the turbidites that were triggered by it. Evidence of both of these perturbations is readily identified from compositional element/Al and $\mathrm{Sr} / \mathrm{Ca}$ profiles that are distinct from those of the enclosing sediments. In one core with a $37 \mathrm{~cm}$ thick Santorini ash layer an oxidation front succeeded in penetrating the whole ash layer after emplacement to form a Mn peak but is now retreating. In cores where thin $(<15 \mathrm{~cm})$ Santorini turbidites or ash layers lie above S1, oxidation fronts initially form additional Mn peaks on top of the turbidites and subsequently alter the characteristic double peaked Mn profile shape usually observed above sapropel S1.
\end{abstract}

(C) 2005 Elsevier B.V. All rights reserved.

Keywords: manganese; Santorini; diagenesis; sapropel S1; eastern Mediterranean; molybdenum

\footnotetext{
* Corresponding author. Present address: Leibniz-Institute of Marine Sciences, IFM-GEOMAR (East Shore Campus), Marine Biogeochemistry, Wischhofstr. 1-3, D-24148 Kiel, Germany. Tel.: +31 30 2534991; fax: +31302535302 .

E-mail addresses: areitz@ifm-geomar.de (A. Reitz), jth@soc.soton.ac.uk (J. Thomson), gdelange@geo.uu.nl (G.J. de Lange), drhg@soc.soton.ac.uk (D.R.H. Green), slomp@geo.uu.nl (C.P. Slomp), cgebhardt@awi-bremerhaven.de (A.C. Gebhardt).
}

\section{Introduction}

Two distinctly separated Mn peaks, generally both with concentrations of $<1 \mathrm{wt} . \% \mathrm{Mn}$, occur in the sediments above the S1 sapropel in the eastern Mediterranean basin [1-4]. The upper peak marks the position of the oxic layer that was present at the top of the sapropel at the end of S1 times [4,5]. Reitz et al. [5] consider that all these high Mn peaks are principally diagenetic in nature even though the large amounts of Mn involved 
probably result from multiple earlier hydrogenous input events. In the near surface sediments of a diapiric area on the crest of the Mediterranean ridge south of Crete this layer has been reported to occur as a prominent dark "Marker Bed" with variable Mn contents of up to 22.8 wt. $\%$ of the total sediment [6]. The formation of this Mn-enriched "Marker Bed" layer was ascribed to an expulsion of hydrothermal fluid, possibly related in some manner to the catastrophic explosive eruption of Santorini [6,7] that occurred between 1599 and 1633 B.C. in the late Bronze Age [8]. The lower of the two Mn peaks is forming actively, solely as a consequence of early diagenesis [4] (for simplification regarding the relative positions of $\mathrm{S} 1$ and the two Mn peaks to each other see figure in Section 3.1). In this latter case, $\mathrm{O}_{2}$ diffusing downwards from oxygenated bottom waters reacts with $\mathrm{Mn}^{2+}$ diffusing upwards in the sediments from anoxic conditions at depth to precipitate $\mathrm{MnO}_{x}$. The maximum Mn content at the lower face of this lower peak therefore marks the present limit of oxic conditions in the sediments, and is located immediately above the dark $C_{\text {org }}$ and sulfide-rich visual (residual) S1 unit. This same high mobility of Mn during early diagenesis leads to the expectation that the sedimentological expressions of Santorini's Minoan eruption might have had some influence on Mn profiles.

The explosive Minoan eruption of Santorini was an event of considerable environmental significance $[9,10]$, and two distinct expressions of the event are found in the eastern Mediterranean deep-sea sediment record. The ash emitted, also known as Mediterranean tephra $\mathrm{Z} 2$, is distinctive in geochemistry and mineralogy [11] and is present as a centimeter-decimeter thick layer in the south-eastern Aegean Sea and in the northwestern Levantine Sea (e.g. [12-14]).

In other deep regions of the eastern Mediterranean, turbidites interpreted to have been triggered by the tsunami induced by the collapse of the Santorini caldera are found [15-19]. These turbidites have all been termed "homogenites" [16], later subdivided into two basic types $\mathrm{A}$ and $\mathrm{B}$ and two specific types $\mathrm{C}$ and D $[17,19]$. Type A is a pelagic turbidite of local provenance that is found at the bottom of small ponded basins of the Calabrian and Mediterranean Ridges. Type B is an abyssal turbidite of distal provenance most likely sourced from the Libyan coast in the Gulf of Sirte that has been found on the Ionian Abyssal Plain and Sirte Abyssal Plains. This Type B homogenite has also been termed the Augias turbidite by Hieke $[18,20]$. The Sirte and Ionian Abyssal Plains are linked through the Ionian Gap, and this turbidite is $>10 \mathrm{~m}$ thick on the floors of both plains. Type B homogenites often have a thick sandy base [19]. Where pres- ent, homogenite and the Z2 tephra intervals are always located above sapropel S1.

Deposition of either an ash or a turbidite in a sufficiently thick layer at the sea floor will influence the redox profile in the pore waters of the underlying sediment. The diffusive penetration of bottom water $\mathrm{O}_{2}$ into the newly deposited surficial sediment layer over time will depend on the rate of $\mathrm{O}_{2}$ consumption by reduced species within it [21]. In the case of turbidites, the main reductants are expected to be $C_{\text {org }}$ and sulfides [22], although ash from Mount Pinatubo has also been shown to consume $\mathrm{O}_{2}$ [23]. The sediments under the turbidite experience a loss of oxygen tension as a consequence of this surface blanketing, which can be expected to affect $\mathrm{Mn}$ speciation and distribution. $\mathrm{MnO}_{x}$ at depth will be reduced by reductants like $\mathrm{Fe}^{2+}$ that are present in anoxic pore waters [24]. The $\mathrm{Mn}^{2+}$ so produced is then free to diffuse upwards to produce new near-surface diagenetic $\mathrm{MnO}_{x}$ peaks where pore water $\mathrm{O}_{2}$ is re-encountered [25-29]. It has been found in the Madeira Abyssal Plain turbidite succession [25,26] and elsewhere [23,27,28,30] that such oxidation fronts advance rapidly over decimeters into the redeposited units, depending on porosity and the concentrations of reductants present (solid phase $C_{\text {org }}$ and sulfide, pore water $\mathrm{Fe}^{2+}$ and $\mathrm{Mn}^{2+}$ ), but rarely achieve $>1 \mathrm{~m}$ penetration. Since the Type B homogenite found on eastern Mediterranean abyssal plains is 10-20 m thick, it follows that the active oxidation front will be located somewhere in the uppermost few decimeters of this unit.

This work investigates the Mn peaks observed in sediments from the Marker Bed area and from other areas where the $\mathrm{S} 1$ sapropel is overlain either by the ash layer or turbidites resultant from the Santorini eruption.

\section{Methods}

Locations and water depths of the cores discussed are presented in Table 1, and their positions in the eastern Mediterranean basin are illustrated in Fig. 1.

The analytical data discussed were obtained at different times on different Inductively Coupled Plasma Atomic Emission Spectroscopy (ICP-AES) instruments in different laboratories; comparison of methods and techniques used were done on selected cores. Data for cores MC12, SL60, SL125, SL139, and BC19 were collected after total dissolution with HF by methods similar to that reported by van Santvoort et al. [4], while those for core T87-19B were collected after a $1: 5$ fusion with $\mathrm{LiBO}_{2}$ by the method of Totland et al. [31]. To monitor precision and accuracy of the methods 
Table 1

Positions and water depths of the cores investigated

\begin{tabular}{llllllr}
\hline Core & Latitude $\left[{ }^{\circ} \mathrm{N}\right]$ & Longitude $\left[{ }^{\circ} \mathrm{E}\right]$ & Type of corer & Ship/year & $\begin{array}{l}\text { Water depth } \\
{[\mathrm{m}]}\end{array}$ & $\begin{array}{c}\text { Upper Mn peak maximum } \\
{[\mathrm{mg} / \mathrm{g}]}\end{array}$ \\
\hline SL60 & $35^{\circ} 39.69^{\prime}$ & $26^{\circ} 34.99^{\prime}$ & Piston & Prof. Logachev/1999 (Smilable) & 1522 & 7.7 \\
SL125 & $33^{\circ} 394^{\prime}$ & $24^{\circ} 32.98^{\prime}$ & Box & Prof. Logachev/1999 (Smilable) & 1946 & 28.6 \\
MC12 & $33^{\circ} 23.7^{\prime}$ & $25^{\circ} 01.3^{\prime}$ & Multi & Marion Dufresne 69/1991 & 2211 & 8.1 \\
BC19 & $33^{\circ} 47.85^{\prime}$ & $28^{\circ} 36.50^{\prime}$ & Box & Marion Dufresne 69/1991 & 2750 & 10.3 \\
SL139 & $34^{\circ} 16.05^{\prime}$ & $1^{\circ} 49.79^{\prime}$ & Box & Prof. Logachev/1999 (Smilable) & 3293 & 8.6 \\
T87-19B & $36^{\circ} 48.9^{\prime}$ & $1^{\circ} 10.7^{\prime}$ & Box & Tyro/1987 & 3483 & 4.3 \\
\hline
\end{tabular}

used, sample duplicates and international as well as inhouse standards were applied.

Mn pore water analyses of BC19 and SL139 were made by Atomic Adsorption Spectrometry (AAS), after onboard sampling according to the method described by van Santvoort et al. [4]. Each sample solution was analyzed in triplicate, and a deviation of less than $10 \%$ was accepted.

$\mathrm{CaCO}_{3}$ was determined after analyzing the total carbon of bulk samples and organic carbon of the decarbonated samples on a Fisons Instruments CNS NA analyzer using dry combustion at $1030{ }^{\circ} \mathrm{C}$.

$\mathrm{CaCO}_{3}$ wt.\%

$$
=\left(C_{\text {tot Wt. } \%}-C_{\text {org Wt. } \%}\right) / 12.01 * 100.09
$$

where $C_{\text {tot }}$ is the measured total carbon, $C_{\text {org }}$ is the organic carbon measured in decarbonated samples and 12.01 and 100.09 are the molar weights of $\mathrm{C}$ and
$\mathrm{CaCO}_{3}$. Removal of inorganic carbon $\left(C_{\text {tot }}-C_{\text {inorg }}\right)$ was achieved by adding $7.5 \mathrm{ml} 1 \mathrm{M} \mathrm{HCl}$ to $\sim 300$ $\mathrm{mg}$ of sediment, shaking for $12 \mathrm{~h}$ than centrifuging off the acid; this step was repeated with a shaking time of $4 \mathrm{~h}$ and subsequently the sediment was washed twice with demineralized water and dried before the $C_{\text {org }}$ analysis. International and in-house standards and duplicates were processed at the same time to monitor the accuracy and precession of the analyses.

Acceleration Mass Spectrometry (AMS) radiocarbon analyses were performed on cleaned and handpicked planktonic foraminifera at the Utrecht University AMS facility (G.J. van de Graaff laboratorium).

Bulk element concentrations (e.g. Fe, $\mathrm{Mn}$ and $\mathrm{Ba}$ ) are normalized to $\mathrm{Al}$ to take account of fluctuations in aluminosilicate content, on the assumptions that the element/Al ratio in detrital material should be relatively constant. Therefore, increases in these ratios are inter-

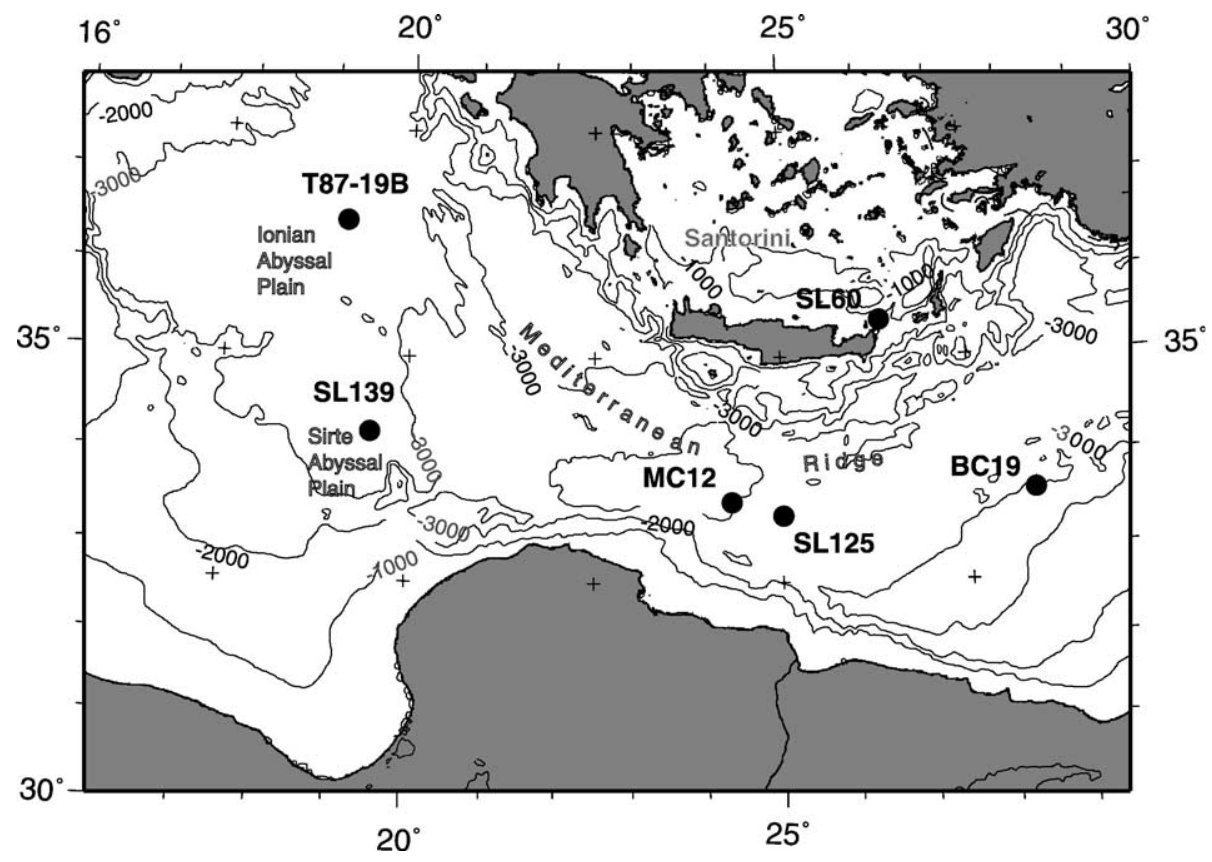

Fig. 1. Map of the eastern Mediterranean with locations of the cores investigated. Bathymetric contours are at $1000 \mathrm{~m}$ intervals. 
preted as due to diagenetic concentrations of these redoxsensitive elements [32].

\section{Results and discussion}

\subsection{A comparison of Mn profiles in the Marker Bed locality}

Box core SL125 was retrieved from the Marker Bed locality on the diapiric crestal area of the Mediterranean Ridge south/southwest of Crete where Cita and co-workers $[6,7]$ reported the highest Mn values. These earlier geochemical investigations on other cores from the same location compared spot samples from the Marker Bed with samples taken a few $\mathrm{cm}$ above and below, so that SL125 is the first core from the area with an unusually large $\mathrm{Mn}$ peak for which detailed and continuous inorganic geochemical profiles have been gathered. These profiles are compared with similar data from another Mediterranean Ridge crest core MC12 (Fig. 2) that have been used to elucidate the post-depositional diagenetic modifications experienced by sapropel S1 [2,3]. Although the upper Mn peak maximum in core SL125 is at the lower end of the wide range of values reported by
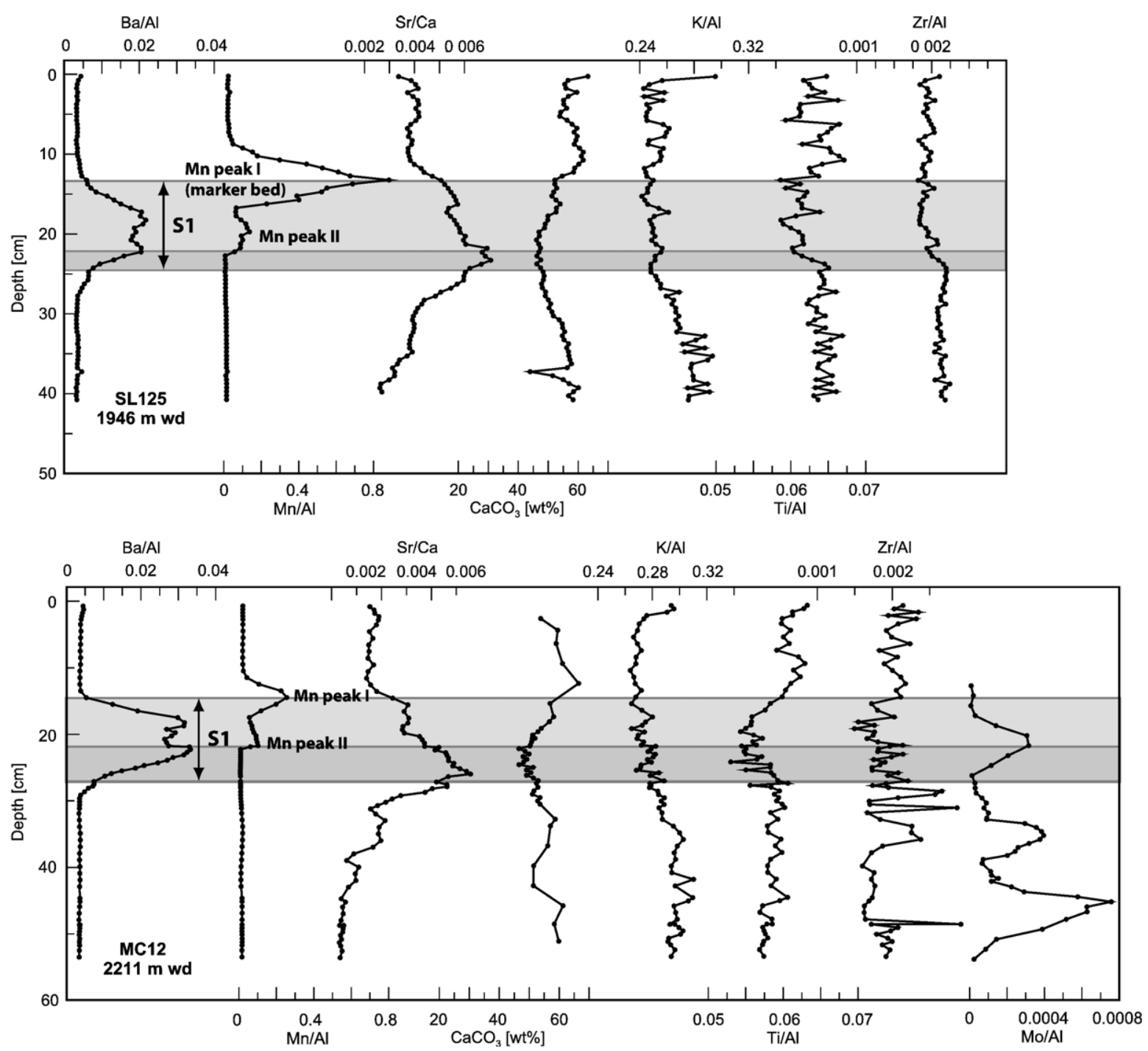

Fig. 2. Element ratios $(\mathrm{Ba} / \mathrm{Al}, \mathrm{Mn} / \mathrm{Al}, \mathrm{Sr} / \mathrm{Ca}, \mathrm{K} / \mathrm{Al}, \mathrm{Ti} / \mathrm{Al}$, and $\mathrm{Zr} / \mathrm{Al})$ and $\mathrm{CaCO}_{3}$ concentration in the sediment versus depth in core $\mathrm{SL} 125$ from $1946 \mathrm{~m}$ water depth (upper panel) and MC12 from $2211 \mathrm{~m}$ water depth (lower panel). The residual S1 and the oxidized S1 zones are illustrated by the dark and light grey shadings, respectively. To generally demonstrate the relative positions of S1 and the two Mn peaks-Mn I that formed first at the end of S1 times, sometimes referred to as the 'Marker Bed' and Mn II that forms actively - these terms have been adapted to the figure. 
De Capitani and Cita [6], the Mn enhancement is substantial at $2.9 \mathrm{wt} . \% \mathrm{Mn}$ compared with $0.8 \mathrm{wt} . \% \mathrm{Mn}$ at the corresponding Mn maximum in core MC12 (Table 1; data not shown in Fig. 2).

The original and visible boundaries of sapropel S1 are defined by criteria described by Thomson et al. [3] from variations of element/Al ratios (Fig. 2). The Mn/ Al profile in both cores shows the typical double peak feature. The upper peak of this feature lies exactly on top of the zone of high $\mathrm{Ba} / \mathrm{Al}$ values that accompany high initial $C_{\text {org }}$ values in sapropels, while the lower peak is situated immediately above the dark residual S1 unit. The coincidence of the upper Mn maximum with the point at which $\mathrm{Ba} / \mathrm{Al}$ values return to the low constant detrital value is characteristic of sapropel S1 times and has also been reported in several other eastern Mediterranean cores $[2,4,5,33,34]$. The position of the lower Mn peaks marks the limit of the post-depositional oxidation of sapropel organic matter that has occurred since formation of the upper Mn peak at the end of S1 times (Fig. 2).

The sapropel $\mathrm{Ba} / \mathrm{Al}$ levels are higher in core $\mathrm{MC} 12$ than in core SL125, while the upper $\mathrm{Mn} / \mathrm{Al}$ peak in SL125 is much larger than that in MC12. The $\mathrm{Sr} / \mathrm{Ca}$ levels are high in and around the sapropel in both cores. This has been attributed to diagenetic aragonite formation that accompanies sulfate reduction in sapropels [35], whereas recent results suggest that a near coastal source may be more important [36]. The $\mathrm{CaCO}_{3}$ and element/Al profiles $(\mathrm{K}, \mathrm{Ti}, \mathrm{Zr})$ are similar in both cores. This comparison of the elemental profiles in the two cores demonstrates both the compositional variability that is found in different $\mathrm{S} 1$ examples and the consistent evidence of the post-depositional oxidation that has been experienced by $\mathrm{S} 1$ units since their formation (Fig. 2).

Mercone et al. [33] reported that the eastern Mediterranean sapropel $\mathrm{S} 1$ formed in the Holocene between $\sim 9.5$ and $6{ }^{14} \mathrm{C}$ ky B.P. Recognizing that marine radiocarbon convention ages underestimate calibrated or dendrochronological time by $350-600$ years in the time range 5.0 to $9.0 \mathrm{ky}$ B.P. [37], the age of the sediments that host the upper Mn peak is $\sim 6 \mathrm{ky}{ }^{14} \mathrm{C}$ convention years B.P. which corresponds to a calibrated age of $\sim 6.4$ ky B.P. More precisely, the host sediments of the upper Mn peak of the core SL125 and the cores BP15 and 18 (cores that have been discussed regarding the origin of the upper Mn peak by Reitz et al. [5]) are $\sim 5.6,6.7$, and $5.0 \mathrm{ky}{ }^{14} \mathrm{C}$ convention B.P. (interpolated age), respectively. The tephra layer of box core $\mathrm{BC} 19$ has an age of about $3.65 \mathrm{ky}{ }^{14} \mathrm{C}$ B.P (calibrated). Accordingly, the upper Mn (Marker Bed) peak pre- dates the Santorini eruption $\sim 3.6 \mathrm{ky}$ ago by $\sim 2.8 \mathrm{ky}$. Even more important, recent work [5] has shown that similar layers with Mn contents of $>3$ wt. $\%$ occur at other eastern Mediterranean localities besides the Marker Bed area, but apparently always at water depths between 1000 and $2000 \mathrm{~m}$. Thus, the fact that the large $\mathrm{Mn}$ peak occurs at different localities in the eastern Mediterranean and that it pre-dates the Santorini event discounts a direct association.

\subsection{The effect of the Santorini tephra layer on Mn diagenesis}

Core SL60 was recovered in the south-east Aegean Sea at $1522 \mathrm{~m}$ water depth (Fig. 1), and Santorini tephra $\mathrm{Z} 2$ is present between 20 and $57 \mathrm{~cm}$, well above the original S1 sapropel at $70-105 \mathrm{~cm}$ (Fig. 3). Core BC19 was retrieved from an abyssal hill at $2750 \mathrm{~m}$ in the western Levantine Basin and is thus more distant from Santorini (Fig. 1). The tephra layer at 6-9 $\mathrm{cm}$ depth in this core is much thinner, but well above the original sapropel $\mathrm{S} 1$ at $16-28 \mathrm{~cm}$. High $\mathrm{Ba} / \mathrm{Al}, \mathrm{K} / \mathrm{Al}, \mathrm{Zr} / \mathrm{Al}$ ratios values and low $\mathrm{Fe} / \mathrm{Al}, \mathrm{Ti} / \mathrm{Al}, \mathrm{Cr} / \mathrm{Al}, \mathrm{Ni} / \mathrm{Al}$ ratios values, and $\mathrm{CaCO}_{3}$ contents differentiate the distinct dark Z2 tephra layers on compositional grounds from the marl sediments that enclose them in both cores (Fig. 3). Although the Santorini ash is considered to be very homogenous in composition (e.g. [38]), the profiles of the element/Al ratios are not "square wave" in shape through the $37 \mathrm{~cm}$ thick ash layer in core SL60. Potential explanations for this inhomogeneity are (i) an evolution in ash composition over the period of the eruption, (ii) a differentiation of the ash during settlement through the water column, and (iii) a contamination of the ash with other sedimentary material. In order to examine these possibilities, two compositional endmembers were calculated from the core SL60 analyses (Fig. 4). One of these, EM1 (end-member 1), is an average of the sediment composition above and below the ash layer, and the other, EM2 (end-member 2), is the mean of three contiguous analyses taken near the base of the ash layer that display the most extreme compositional contrasts (highest $\mathrm{Ba} / \mathrm{Al}$ and $\mathrm{Zr} / \mathrm{Al}$, lowest $\mathrm{Cr} / \mathrm{Al}$ and $\mathrm{Ni} / \mathrm{Al}$ ratios, and lowest $\mathrm{CaCO}_{3}$ contents; Fig. 3; Table 2).

Geochemical analyses aimed at confirming a Santorini origin for ashes from different locations tend to compare the compositions of glass fractions that have been cleaned before analysis so as to be free from crystalline components and other contamination (e.g. [38,41-43]). By contrast, the core analyses here were bulk geochemical analyses, gathered by sequentially 

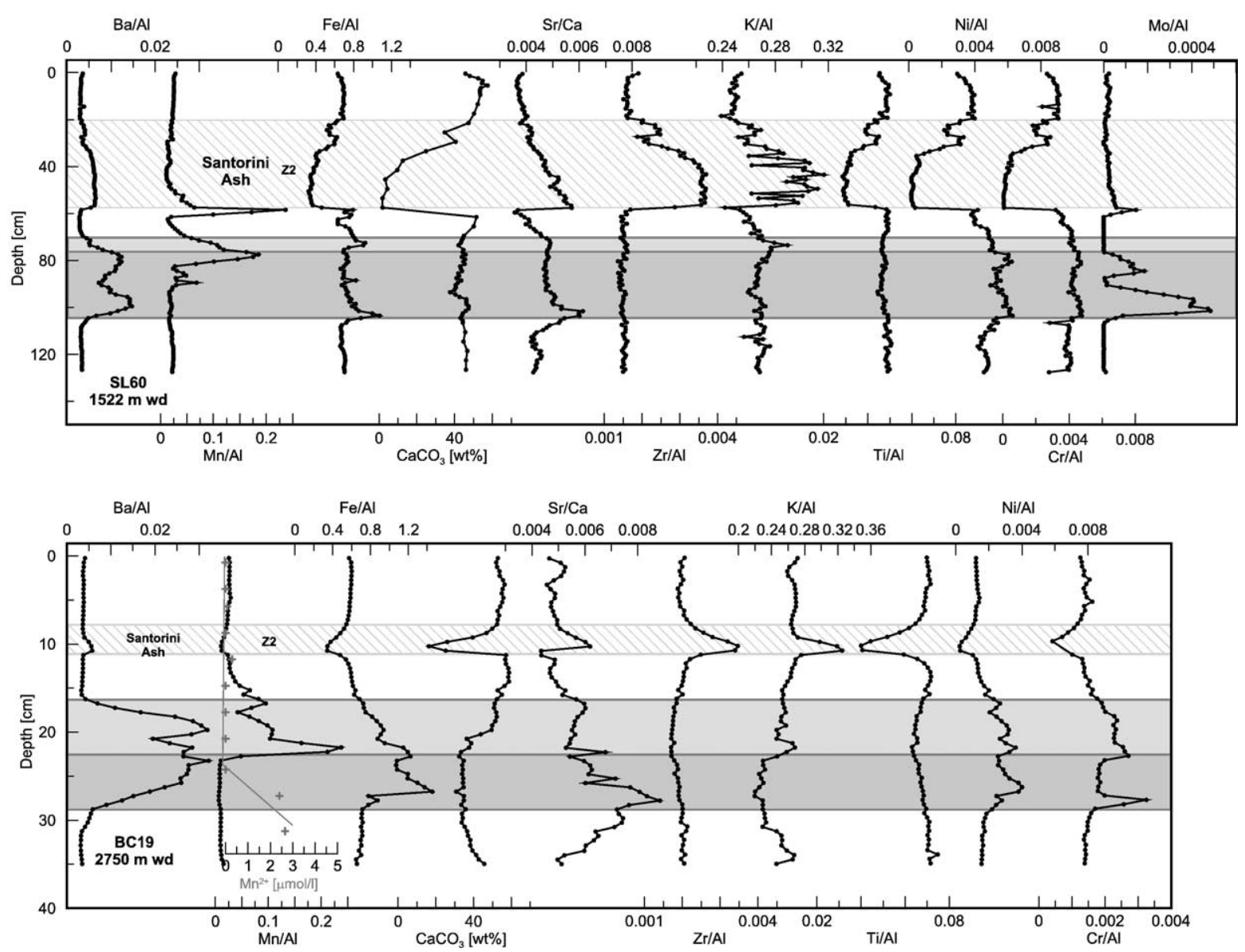

Fig. 3. Element ratios of $\mathrm{Ba} / \mathrm{Al}, \mathrm{Mn} / \mathrm{Al}, \mathrm{Fe} / \mathrm{Al}, \mathrm{Sr} / \mathrm{Ca}, \mathrm{Zr} / \mathrm{Al}, \mathrm{K} / \mathrm{Al}, \mathrm{Ti} / \mathrm{Al}, \mathrm{Ni} / \mathrm{Al}, \mathrm{Cr} / \mathrm{Al}$, and $\mathrm{Mo} / \mathrm{Al}$ (core $\mathrm{SL} 60$ only) and $\mathrm{CaCO} 3$ concentration in the sediment and pore water $\mathrm{Mn}^{2+}$ concentration (core BC19 only) versus depth in cores SL60 from $1522 \mathrm{~m}$ water depth (upper panel) and BC19 from $2750 \mathrm{~m}$ water depth (lower panel). The residual S1 and the oxidized S1 zones are illustrated by the dark and light grey shadings, respectively. Original element concentrations are $\mu \mathrm{g} / \mathrm{g}$ unless otherwise indicated. The Santorini ash layers are indicated by diagonal shading.

cutting wet sediment from the core, and analyzing dried and ground total sediment that included pore water salt. Comparison of the published glass analyses with the core SL60 ash end-member (Table 2) indicate that the latter is likely to be slightly contaminated with $\mathrm{CaCO}_{3}$ because its $\mathrm{Ca}, \mathrm{Mg}$ and $\mathrm{Sr}$ contents are all higher than published ash compositions. The higher $\mathrm{Mn}$ content is due to post-depositional formation of $\mathrm{MnO}_{x}$ that is present as a peak at the base of the ash bed as discussed below (Fig. 3), and the higher $\mathrm{Na}$ content is likely due to the pore water salt content. When the data are plotted in a ternary diagram with $\mathrm{Ca}$, Ti, and $\mathrm{Zr}$ apices selected to separate the EM1 and EM2 sediment compositions (Fig. 4), data from the visual ash layer in cores SL60 and BC19 plot on a mixing line between the calculated SL60 EM2 (ash) and the EM1 (background) sediment composition. This suggests that the visual ash layers in the cores (Fig. 3) are actually a mixture of Santorini ash and sediment, although the question remains open as to whether this mixing occurred during deposition of the layer, or after deposition by bioturbation mixing.

The ash layer of SL60 consists of two sub layers that are clearly distinguishable by the apparent interruption (at $\sim 28 \mathrm{~cm}$ core depth) of the characteristic elemental profiles (Fig. 3). The upper layer could be the Kolomvos ash layer that was emitted about 2000 years ago from a volcanic eruption in the South Aegean Sea $[44,45]$. However, the average element concentration of this layer shows a good agreement of some elements (Al, Zr, Ba; Table 2) with the Z2 (SL60 and BC19) but some other elements $(\mathrm{Mg}, \mathrm{Sr}, \mathrm{Cr}, \mathrm{Co}, \mathrm{Ni})$ agree nicely with the background sediments. Thus it is impossible to group this layer clearly to the Z2 or deny a sort of unity. The data points of this upper layer follow in fact the mixing line of the EM1 and the EM2 sediment of the SL60 yet they plot much closer to the background data (EM1; Fig. 4). It could thus be that it is (i) a secondary 


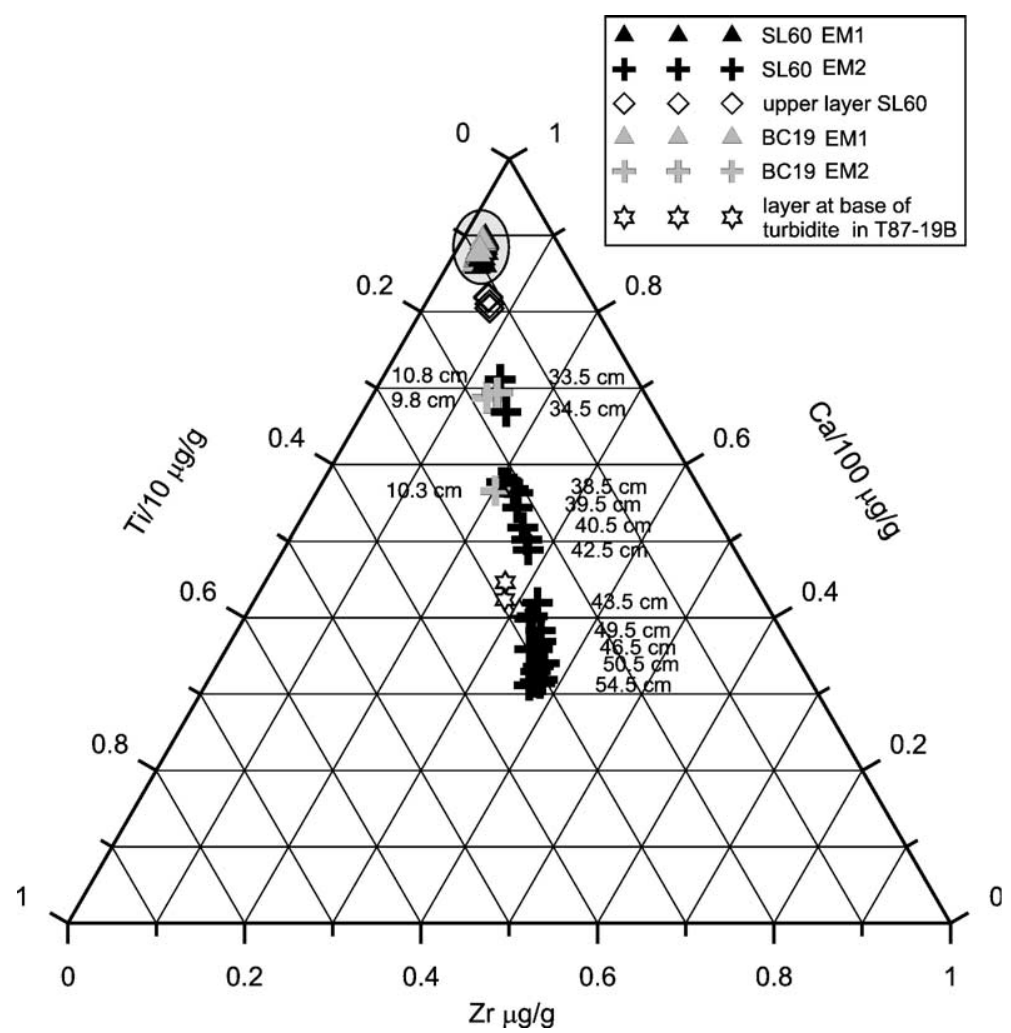

Fig. 4. Ternary plot of $\mathrm{Ca} / 100 \mu \mathrm{g} / \mathrm{g}$ (main element in biogenic carbonates), $\mathrm{Ti} / 10 \mu \mathrm{g} / \mathrm{g}$ (mainly introduced by terrigenous material and the ash), and $\mathrm{Zr} \mu \mathrm{g} / \mathrm{g}$ (enriched in the ash). Labels on the right are sediment depths in SL60 and those on the left are from BC19. The background composition is indicated by the shading.

and possibly additionally, bioturbated phase of the Z2 ash layer that took much longer to settle through the water column, (ii) a minor turbidite of upper ash composition, or (iii) later wash-in of Santorini ash from land surfaces rather than ash material from a different volcanic eruption. However, these possibilities are rather speculative and it is not the target of this paper to classify the ash layers above S1 but to study their effects on the manganese behavior.

In the S1 layers of cores SL60 and BC19 the Ba/Al, $\mathrm{Fe} / \mathrm{Al}$, and $\mathrm{Sr} / \mathrm{Ca}$ ratios are high, particularly in the residual (visual) units. The $\mathrm{Mn} / \mathrm{Al}$ profiles in these two cores are more complex than the Mn profiles of cores MC12 and SL125. In the core SL60 Mn profile two large peaks are present, one that gradually increases with depth near the base of the ash with a sharp maximum immediately under the ash base at $59 \mathrm{~cm}$, and a distinct but broader peak that lies in the top of the S1 unit. All $37 \mathrm{~cm}(20-57 \mathrm{~cm})$ of the coarse ash layer in core SL60 appears to have been penetrated by bottom water $\mathrm{O}_{2}$ at some time since its emplacement. The evidence for this penetration is the Mn peak that begins at $\sim 50 \mathrm{~cm}$ depth in the ash with the Mn maximum at 59 $\mathrm{cm}$ and a sharp cut-off at $61 \mathrm{~cm}$. This peak shape, with a marked increase with depth and a sharp basal cut-off, is that expected to develop at a progressive oxidation front when a diffusive downwards flux of $\mathrm{O}_{2}$ from bottom waters reacts with an upwards flux of $\mathrm{Mn}^{2+}$ to form $\mathrm{MnO}_{x}[30,46]$ and is also a shape that can be recognized in many lower $\mathrm{Mn}$ peaks in sapropel S1 (e.g. that of MC12 in Fig. 2). Haeckel et al. [23] found that bottom water $\mathrm{O}_{2}$ had penetrated $\sim 5 \mathrm{~cm}$ into the tephra layer deposited from the 1991 Mount Pinatubo explosion in only 7 years, so both Santorini ash layers here are expected to have been fully oxidized in the 3600 years since their emplacement.

The S1 sapropel at the shallower water location of core SL60 is in the form of two $\mathrm{Ba} / \mathrm{Al}$ profile lobes between 70 and $105 \mathrm{~cm}$, and these sediments were deposited so rapidly that the post-depositional oxidation experienced by most other S1 sapropels is very limited [47]. The Mn peak that sits inside but just below the top of the sapropel unit is no longer expected to be present as $\mathrm{MnO}_{x}[33,47]$ because it is located so deep in the sediment that pore water conditions must now be anoxic. It is more likely that this peak represents authigenic Mn-carbonate (e.g. kutnahorite) that originated by anoxic dissolution of a $\mathrm{MnO}_{x}$ peak. Due to the 
Table 2

Element end-member concentrations of the background (EM1) and the ash layer (EM2) sediments in cores SL60 and BC19 as well as of the turbidite base of T87-19B

\begin{tabular}{|c|c|c|c|c|c|c|c|c|c|c|}
\hline Element & Unit & $\begin{array}{l}\text { SL60 EM1 } \\
\text { (background sediment) } \\
\text { bulk ICP-AES }\end{array}$ & $\begin{array}{l}\text { BC19 EM1 } \\
\text { (background sediment) } \\
\text { bulk ICP-AES }\end{array}$ & $\begin{array}{l}\text { SL60 EM2 } \\
\text { (Z2) bulk } \\
\text { ICPAES }\end{array}$ & $\begin{array}{l}\text { BC19 EM2 } \\
\text { (Z2) bulk } \\
\text { ICPAES }\end{array}$ & $\begin{array}{l}\text { T87-19B } \\
\text { turbidite base } \\
\text { bulk ICP-AES }\end{array}$ & $\begin{array}{l}\text { Bulk pumice, } \\
\text { Schmid et al. [38] } \\
\text { XRF }\end{array}$ & $\begin{array}{l}\text { Glass fraction, } \\
\text { Schmid et al. [38] } \\
\text { XRF }\end{array}$ & $\begin{array}{l}\text { Ash analysis, } \\
\text { Peltz and Bichler [39] }\end{array}$ & $\begin{array}{l}\text { Minoan Bo-1, } \\
\text { Santorini glass, } \\
\text { Hammer et al. [40] }\end{array}$ \\
\hline & & $n=30$ & $n=52$ & $n=3$ & $n=3$ & $n=4$ & & & & \\
\hline $\mathrm{CaCO} 3$ & $\%$ & 50.7 & 55.5 & 1.86 & 20.75 & & & & & \\
\hline $\mathrm{Al}$ & & 4.1 & 3.3 & 7.92 & 6.34 & 1.06 & 7.44 & 7.00 & 7.52 & 7.32 \\
\hline $\mathrm{Mg}$ & & 2.9 & 1.9 & 0.70 & 0.99 & 1.93 & 0.48 & 0.28 & & 0.21 \\
\hline $\mathrm{K}$ & & 1.0 & 0.9 & 2.28 & 2.04 & 3.36 & 2.40 & 2.70 & 2.5 & 3.10 \\
\hline $\mathrm{Na}$ & & 1.3 & 1.2 & 3.84 & 3.06 & 5.41 & 3.40 & 3.30 & 3.57 & 2.40 \\
\hline $\mathrm{Fe}$ & & 2.9 & 2.0 & 2.73 & 2.18 & 3.12 & 2.22 & 1.64 & 2.12 & 1.73 \\
\hline Mn & & 0.2 & 0.1 & 0.33 & 0.07 & 0.09 & 0.07 & 0.05 & 0.06 & 0.14 \\
\hline $\mathrm{S}$ & & 0.1 & 0.2 & 0.07 & 0.15 & & & & & \\
\hline $\mathrm{Ti}$ & & 0.2 & 0.2 & 0.23 & 0.26 & 0.28 & 0.27 & 0.19 & 0.26 & 0.36 \\
\hline $\mathrm{Ca}$ & & 19.2 & 22.2 & 2.46 & 8.31 & 4.94 & 1.60 & 1.10 & 1.45 & 1.3 \\
\hline $\mathrm{Sr}$ & $\mathrm{ppm}$ & 754.2 & 1086.5 & 134.33 & 421.77 & 674.4 & & & & 72 \\
\hline $\mathrm{Cu}$ & & 37.6 & 44.6 & 15.67 & 27.22 & & & & & \\
\hline $\mathrm{V}$ & & 68.2 & 55.7 & 39.68 & 40.11 & 92.9 & & & 23 & 13 \\
\hline $\mathrm{Zn}$ & & 63.4 & & 67.45 & & 74.0 & & & 55 & \\
\hline $\mathrm{P}$ & & 407.7 & 427.3 & 376.80 & 392.58 & 1298.7 & & & & \\
\hline $\mathrm{Ba}$ & & 127.5 & 120.7 & 510.56 & 358.22 & 734.9 & 479.00 & & 556 & 690 \\
\hline $\mathrm{Cr}$ & & 142.1 & 47.0 & 3.79 & & 18.5 & & & & 1.7 \\
\hline $\mathrm{Co}$ & & 19.6 & 15.0 & 8.16 & 10.13 & & & & 4 & \\
\hline $\mathrm{Ni}$ & & 163.2 & 46.5 & 12.74 & 15.60 & 27.8 & & & & \\
\hline $\mathrm{Y}$ & & 14.9 & 16.5 & 38.16 & 36.23 & 16.0 & & & & 32.5 \\
\hline $\mathrm{Zr}$ & & 64.8 & 65.9 & 217.72 & 249.73 & 280.1 & 286.00 & & 271 & 292 \\
\hline
\end{tabular}

For piston core SL60 the EM2 composition was calculated from the samples at 52.0-54.5 cm, and the EM1 composition from the samples at 0-18.5 and $58-69.5 \mathrm{~cm}$. For box core BC19 the EM2 composition was calculated from the samples at $10.25-10.88 \mathrm{~cm}$ and the EM1 composition was calculated from the samples at 0-8.38 and $11.5-16.13 \mathrm{~cm}$. For box core T87-19B the composition of the turbidite base was calculated from samples at $16.25-17.75 \mathrm{~cm}$. For comparison published element concentrations of Santorini ash are listed. 
anoxic conditions alkalinity is expected to increase as well as the concentration of $\mathrm{Mn}^{2+}$ in pore water, which favors Mn-carbonate precipitation [48] in these sediments that contain more than 40 wt. $\% \mathrm{CaCO}_{3}$.

Reitz et al. [5] have demonstrated that Mo is sorbed from bottom waters on to $\mathrm{MnO}_{x}$ in eastern Mediterranean sediments at a $\mathrm{Mn}$ : Mo ratio of $\sim 600: 1$, and have suggested that this value increases as Mo is preferentially lost from $\mathrm{MnO}_{x}$ on reduction [49]. Where Mo is measurable in core SL60 (only concentrations $>1.5 \mu \mathrm{g}$ $\mathrm{g}^{-1}$ appear to be reliable), the $\mathrm{Mo} / \mathrm{Al}$ ratio displays 3 peaks; the upper two of which are coincident with the two Mn peaks and the lowest coincides with sulfides in the residual sapropel. The Mn:Mo ratio is $\sim 1500: 1$ at the shallower Mn peak and $\sim 1900: 1$ at the deeper Mn peak. These Mn: Mo ratios are similar to the ratio of 1700:1 measured in an Adriatic core where Mo had been lost when $\mathrm{MnO}_{x}$ was reduced and converted to kutnahorite $\left[(\mathrm{Mn}, \mathrm{Ca}) \mathrm{CO}_{3}\right]$ [5]. From the $\mathrm{Mn}$ : Mo ratios in core SL60, it is inferred that the active oxidation front may now be around $45 \mathrm{~cm}$ depth because $\mathrm{Mn} / \mathrm{Mo}$ values of $>500$ are found at all greater depths.
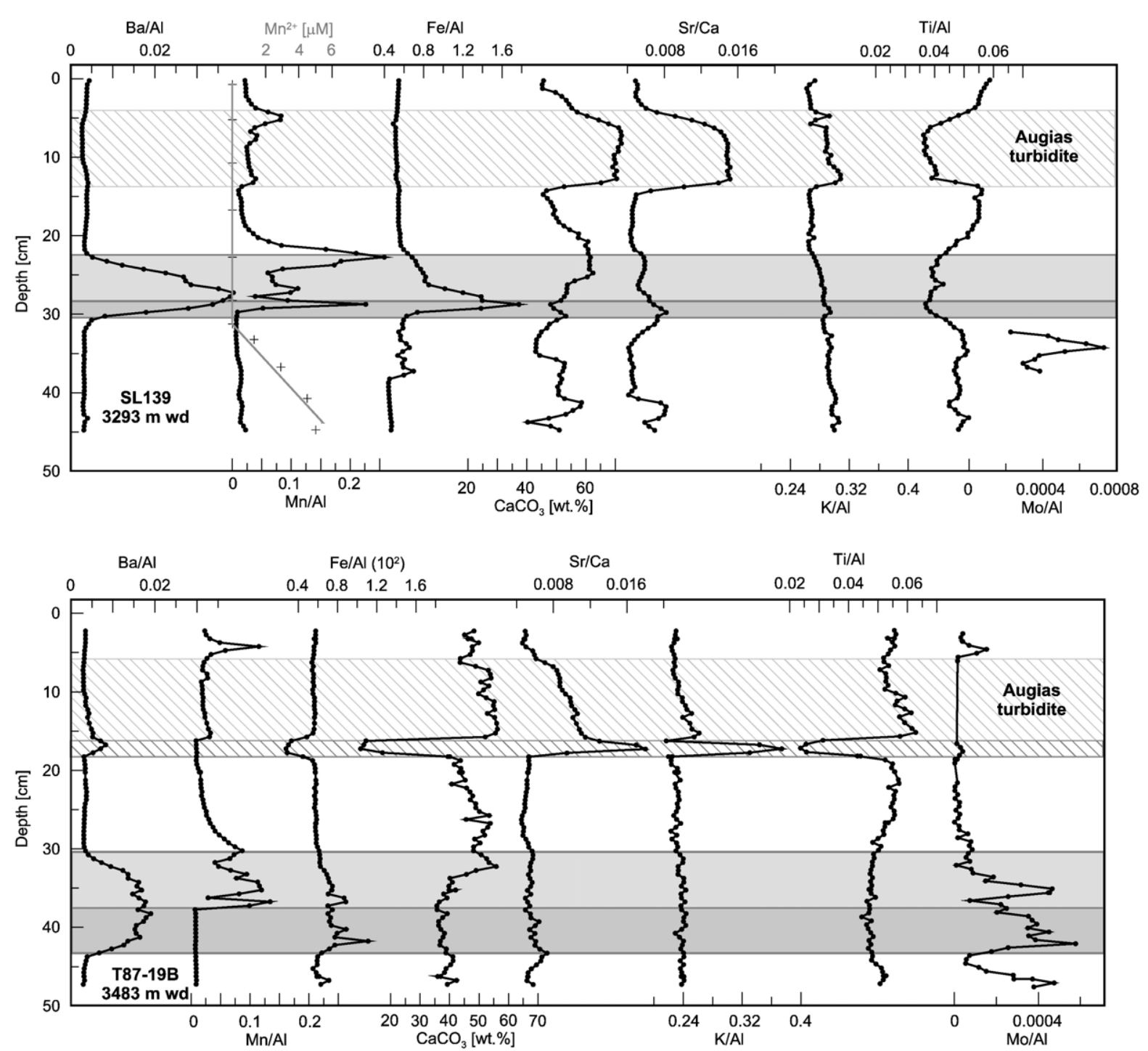

Fig. 5. Element ratios $(\mathrm{Ba} / \mathrm{Al}, \mathrm{Mn} / \mathrm{Al}, \mathrm{Fe} / \mathrm{Al}, \mathrm{Sr} / \mathrm{Ca}, \mathrm{K} / \mathrm{Al}, \mathrm{Ti} / \mathrm{Al}$, and $\mathrm{Mo} / \mathrm{Al})$ and concentrations of $C_{\text {org }}, \mathrm{CaCO}_{3}$, and pore water $\mathrm{Mn}^{2+}(\mathrm{SL} 139$ only) versus depth in cores SL139 from $3293 \mathrm{~m}$ water depth (upper panel) and T87-19B from $3483 \mathrm{~m}$ water depth (lower panel). The residual S1 and the oxidized S1 zones are illustrated by the dark and light grey shadings, respectively. Original element concentrations are $\mu \mathrm{g} / \mathrm{g}$ unless otherwise indicated. The Augias turbidite is indicated by diagonal shading and in core T87-19B a layer of different composition is indicated by darker diagonal shading. 
The Mn profile of core $\mathrm{BC} 19$ has similarities with the general pattern seen elsewhere in the eastern Mediterranean (e.g. Fig. 2), with two distinct Mn peaks (Fig. $3)$. The upper Mn peak maximum is located at the top of the high $\mathrm{Ba} / \mathrm{Al}$ values that mark the original $\mathrm{S} 1$, while the lower Mn peak has its maximum with an abrupt cut off just above the residual S1 unit. Pore water data for this core reveal that $\mathrm{Mn}^{2+}$ from depth in the sediments is being supplied to the base of the lower Mn peak, which in this case is the larger of the two $\mathrm{Mn}$ peaks. It is expected that bottom water $\mathrm{O}_{2}$ would rapidly penetrate the thin ash layer in this core after its deposition. Nevertheless, the additional material added at the sediment surface by the ash layer must have decreased the flux of $\mathrm{O}_{2}$ available at depth that is consumed in oxidation of either sapropel $C_{\text {org }}$ or pore water $\mathrm{Mn}^{2+}$. This corresponds to the change in slope seen in the shape of the lower Mn peak; more of the available $\mathrm{O}_{2}$ flux has been consumed in $\mathrm{Mn}^{2+}$ precipitation rather than $C_{\text {org }}$ oxidation since the ash fall event, which consequently slows down the downward migration of the oxidation front.

It has been shown that there are large differences in the effect of the Z2 on Mn diagenesis in both cores discussed. To briefly generalize these differences it can be said that a thick ash layer (SL60) results in a large burial that produces considerable $\mathrm{MnO}_{x}$ dissolution and a large diagenetic $\mathrm{MnO}_{x}$ peak at the base of the $\mathrm{Z2}$ tephra. A thin ash layer (BC19) produces little $\mathrm{MnO}_{x}$ dissolution and relatively minor changes in $\mathrm{Mn}$ redistribution through diagenesis.

\subsection{The effect of Santorini turbidites on Mn diagenesis}

As described in the introduction, a post-emplacement oxidation front must now be located in the upper reaches of the Augias turbidite on the abyssal plains because of its considerable thickness. Cores SL139 and T87-19B were retrieved well above the floors of the Sirte and Ionian Plains, respectively (unpublished cruise report, G. de Lange et al., 1999; [50]), and in both cores the Augias turbidite is present as a much thinner but compositionally distinct unit. In the nomenclature of Cita et al. [17], both these examples are type $\mathrm{C}$ homogenites that are formed from upslope flow of the material that mainly deposited on the abyssal plains as type B homogenites. Core SL139 was retrieved from $3293 \mathrm{~m}$ water depth and the original sapropel S1 lies at 22-30 cm with the turbidite at 4-14 $\mathrm{cm}$, while core T87-19B was retrieved from $3483 \mathrm{~m}$ water depth and the original sapropel $\mathrm{S} 1$ is at $30-43 \mathrm{~cm}$ and the turbidite is at $6-18 \mathrm{~cm}$. Excluding the turbidite thickness, overall accumulation rates based on an age of $\sim 10 \mathrm{ky}$ at the base of S1 are $\sim 2.2 \mathrm{~cm} \mathrm{ky}^{-1}$ for SL139 and $\sim 3.0 \mathrm{~cm} \mathrm{ky}^{-1}$ for T87-19B.

The unusual feature of the Augias turbidite is its high concentration of detrital aragonite in a deep water setting [18,20], and in cores SL139 and T87-19B this aragonite is evident through $\mathrm{Sr} / \mathrm{Ca}$ values that are much higher than those found in biogenic low-Mg calcite or pteropod aragonite [35,51]. In both cores the $\mathrm{Sr} / \mathrm{Ca}$, $\mathrm{Mn} / \mathrm{Al}, \mathrm{Ca} / \mathrm{Al}$ and $\mathrm{Ti} / \mathrm{Al}$ profiles show a grading from the coarser bases of the turbidite units to the finer tops (Fig. 5). The compositional characteristics of this turbidite are inherited from its shallow water source sediments, with the high $\mathrm{Sr} / \mathrm{Ca}$ ratio derived from a high algal aragonite content and heavy minerals delivering high Ti and $\mathrm{Zr}$ contents [20]. The compositions of the Augias turbidite and the background sediments in cores SL139 and T87-19B are not identical, as can be seen in the $\mathrm{Ca}, \mathrm{Sr}$ and Ti ternary data plot (Fig. 6). Some lateral as well as vertical inhomogeneity might be expected in such a large turbidite with a volume estimated as up to $162 \mathrm{~km}^{3}$ [52].

The $\sim 2 \mathrm{~cm}$ thick layer at the base of the turbidite in core T87-19B has a distinctly different composition from the remainder of the turbidite. These compositional differences might be caused by a heavy mineral component contributed from the shallow water source of the turbidite, but the composition of this layer has similarities with the Z2 ash discussed above (i.e. high $\mathrm{Ba}$ and $\mathrm{Zr}$, low $\mathrm{Ca}$ and $\mathrm{Cr}$; Table 2). Plotting the three data points from this layer on the $\mathrm{Ca}, \mathrm{Ti}, \mathrm{Zr}$ ternary diagram, constructed to display the mixing of Santorini ash and the background sediments of cores SL60 and $\mathrm{BC} 19$, shows that the basal layer of the turbidite in core T87-19B may in fact be Santorini ash underlying the Augias turbidite (Fig. 4).

The Mn profiles in both cores are complex but very similar, with small $\mathrm{Mn} / \mathrm{Al}$ peaks on top of both turbidite layers at $4-5 \mathrm{~cm}$, an increase $\mathrm{Mn} / \mathrm{Al}$ towards the base of the units, and three Mn maxima in the oxidized zone of the S1 sapropel (Fig. 5) rather than two as seen in other cores (e.g. Fig. 2). These Mn profiles are best considered in the context of the diagenetic readjustments that have been demonstrated to occur in response to the deposition of recent turbidites. That work [2729] demonstrates that $\mathrm{Mn}$ from the sediment surface that was buried by the turbidite is reduced and migrates as $\mathrm{Mn}^{2+}$ up through the turbidite body to form $\mathrm{MnO}_{x}$ at the new sediment/water interface at the turbidite top. This is the likely cause of the Mn peaks at $4-5 \mathrm{~cm}$ in both cores. The length of time required for bottom water $\mathrm{O}_{2}$ to penetrate the $10-12 \mathrm{~cm}$ thick Augias 


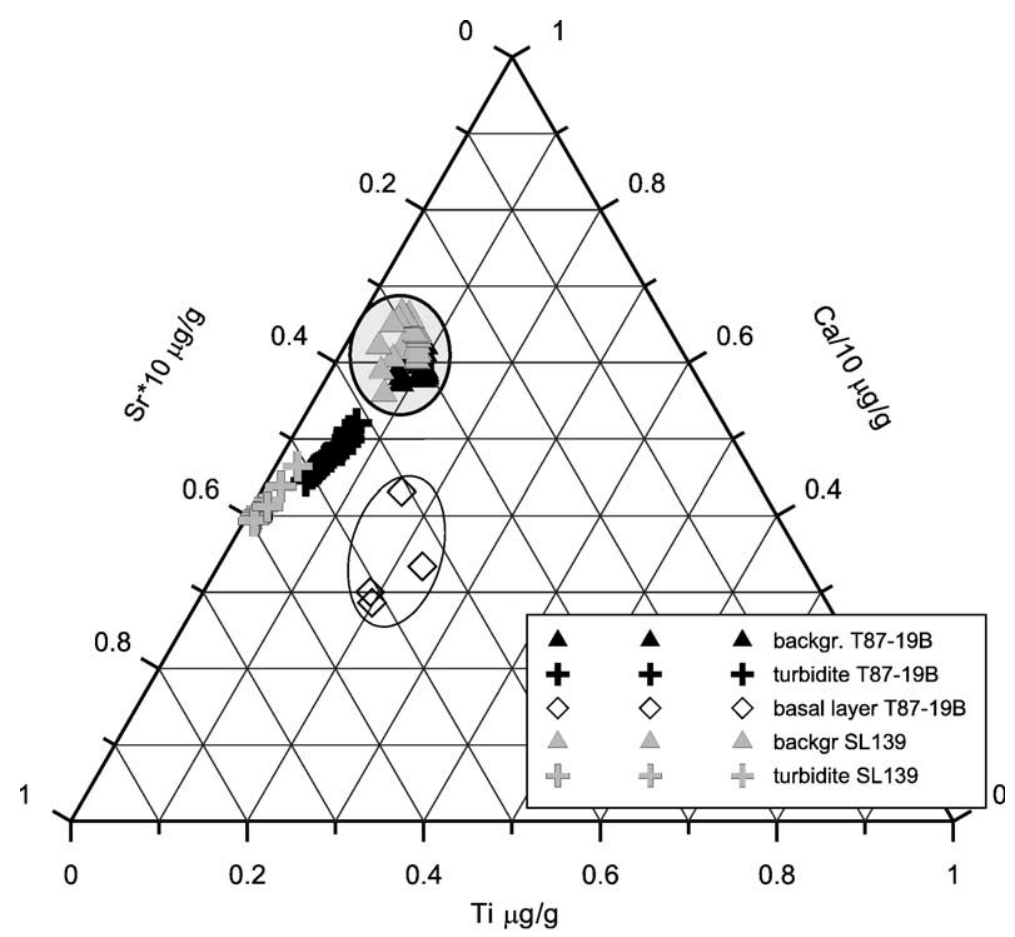

Fig. 6. Ternary plot of $\mathrm{Ca} / 10 \mu \mathrm{g} / \mathrm{g}$ (main element in biogenic carbonates), $\mathrm{Ti} \mu \mathrm{g} / \mathrm{g}$ (mainly introduced by terrigenous material), and $\mathrm{Sr} * 10 \mu \mathrm{g} / \mathrm{g}$ (enriched in 'Augias turbidite' aragonite). The background composition is indicated by the shading and the open ellipse indicates the divergent composition of the basal layer of T87-19B.

turbidite layer in these two cores will depend on porosity and the reductant content in the redeposited sediment [22]. The Mn content increases with depth in the lower part of both turbidite units, but it is not clear whether this is a consequence of the passage of the oxidation front through the turbidite with precipitation of $\mathrm{MnO}_{x}$ (as expected from a diffusive oxidation front and observed in the Santorini ash of core SL60), or whether it is a grading effect in the turbidite body (note that $\mathrm{Sr} / \mathrm{Ca}, \mathrm{Ti} / \mathrm{Al}$ and $\mathrm{Zr} / \mathrm{Al}$ profiles also plot about 4 ky B.P.

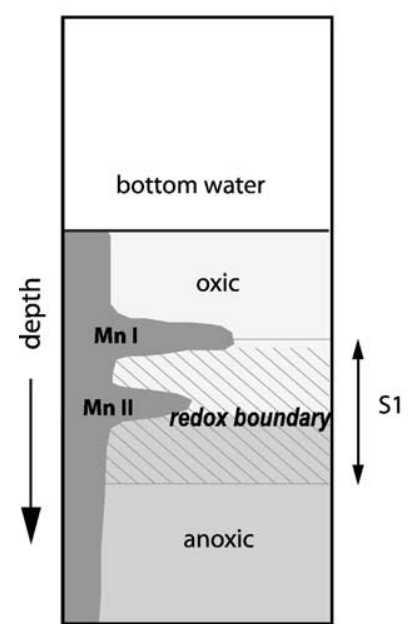

about 3.6 ky B.P.

(after rapid accumulation of Santorini ash/turbidite)

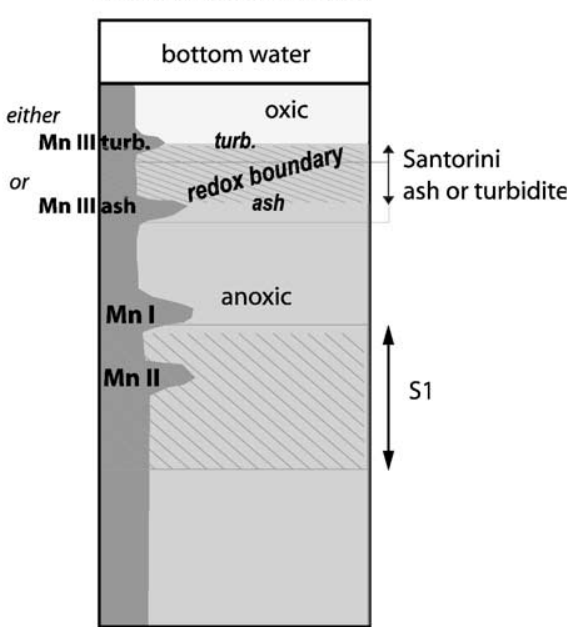

Fig. 7. Conceptual model sketch demonstrating the migration of the Mn deposition zone after rapid accumulation of Santorini ash and turbidite sediments about 3.6 ky B.P., including simplified solid phase Mn profiles as well as S1 and ash/turbidite layers. 
with a gradient in both turbidites; Fig. 5). The Mn profile shape now observed in both cores may represent some combination of these two effects.

The Mn peaks in the oxidized S1 units are at 23, 27, and $29 \mathrm{~cm}$ depth in core SL139 and 30,35 and $37 \mathrm{~cm}$ depth in core T87-19B. In both cores the uppermost of the three Mn peaks is coincident with the upper limit of the high sapropel $\mathrm{Ba} / \mathrm{Al}$ values and thus corresponds to the upper Mn peak in other S1 units (Fig. 2). It is then likely that one of the other two Mn peaks must mark the penetration depth of $\mathrm{O}_{2}$ at the time of turbidite emplacement, while the other must mark the present locus of oxidation (usually the lower Mn peak maximum in other S1 units). Pore water data for SL139 reveal that the lowest peak is actively forming through supply of pore water $\mathrm{Mn}^{2+}$ from deeper sediments (Fig. 5). For T87-19B it is similarly believed that the lower of the three Mn peaks marks the current limit of oxidation. As in the case of the Santorini ash layer in core BC19, it can be assumed that the turbidite layer was rapidly penetrated by bottom water $\mathrm{O}_{2}$. But the $\mathrm{O}_{2}$ flux from bottom water must have been less than the flux available before turbidite emplacement because of the new longer diffusion distance from the sediment/water interface to the residual sapropel.

Where Mo was measurable in core T87-19B, the $\mathrm{Mn}:$ Mo ratio over the $\mathrm{Mn}$ peak at the top of the turbidite is $\sim 660$, similar to the Mn: Mo ratio of 600 that has been established for $\mathrm{MnO}_{x}$ precipitating under oxic conditions [5]. The $\mathrm{Mn}$ : Mo ratios at the three $\mathrm{Mn}$ maxima are $\sim 1020,320$, and 480 from the top of the original S1 to the top of the remaining S1. It therefore seems that the upper Mn peak experienced some loss of Mo during the time that it took $\mathrm{O}_{2}$ to penetrate through the Augias Turbidite. The ratios of the middle and deepest of the three peak appear to have either lost Mn or gained Mo compared with that usually observed for $\mathrm{MnO}_{x}$ precipitated in oxic conditions, or it may be that Mo has been redistributed in some fashion between the three Mn peaks.

\section{Conclusions}

It has been demonstrated that $\mathrm{Mn}$ diagenesis in eastern Mediterranean sediments is influenced by both the tephra and turbidite sediments linked to the Santorini eruption. The rapid accumulation of the tephra or turbidite deposit pushes previously formed $\mathrm{MnO}_{x}$ fronts in the anoxic zone of the sediments (Fig. 7). Subsequently, these $\mathrm{MnO}_{x}$ layers that are now positioned in the anoxic zone will become reduced producing $\mathrm{Mn}^{2+}$, which diffuses upwards. Consequently, new $\mathrm{MnO}_{x}$ peaks will form where upwards diffusing $\mathrm{Mn}^{2+}$ is oxidized by downwards diffusing $\mathrm{O}_{2}$. Moreover, it has been established that the Mn enrichment in the sediments of the diapiric Mediterranean Ridge crest that has been termed the Marker Bed is hosted in sediments that are $\sim 2800$ years older than the Santorini eruption. Such $\mathrm{Mn}$ peaks were formed at the end of the period of sapropel S1 deposition elsewhere in the eastern Mediterranean, and thus clearly predate the Santorini event and cannot be related to it.

\section{Acknowledgements}

This work was partly funded by EU-MAST-III project MAS3-CT97-0137, Sapropels and Paleoproductivity (SAP) and NWO-project Sapropel-related Paleoceanographic Studies in Sediments of the eastern Mediterranean (SAPS). Two anonymous reviewers are thanked for their critical and constructive suggestions and comments. We are grateful to Simon Troelstra of The Free University, Amsterdam for the provision of samples from core T87-19B. We thank H. de Waard for her contribution to the sample preparation and analysis and the crew and the shipboard parties of the cruises named in Table 1 for their contribution to the sample collection. This is NSG contribution no. 20051101.

\section{References}

[1] N.C. Higgs, J. Thomson, T.R.S. Wilson, I.W. Croudace, Modification and complete removal of eastern Mediterranean sapropels by postdepositional oxidation, Geology 22 (1994) 423-426.

[2] J. Thomson, N.C. Higgs, T.R.S. Wilson, I.W. Croudace, G.J. de Lange, P.J.M. van Santvoort, Redistribution and geochemical behaviour of redoxsensitive elements around S1, the most recent eastern Mediterranean sapropel, Geochim. Cosmochim. Acta 59 (1995) 3487-3501.

[3] J. Thomson, D. Mercone, G.J. de Lange, P.J.M. van Santvoort, Review of recent advances in the interpretation of Eastern Mediterranean sapropel S1 from geochemical evidence, Mar. Geol. 153 (1999) 77-89.

[4] P.J.M. van Santvoort, G.J. De Lange, J. Thomson, H. Cussen, T.R.S. Wilson, M.D. Krom, K. Strohle, Active post-depositional oxidation of the most recent sapropel (S1) in the eastern Mediterranean, Geochim. Cosmochim. Acta 60 (1996) 4007-4024.

[5] A. Reitz, J. Thomson, G.J. de Lange, Source and development of large manganese enrichments above eastern Mediterranean sapropel S1, submitted for publication.

[6] L. De Capitani, M.B. Cita, The "marker bed" of the Mediterranean Ridge diapiric belt: geochemical characteristics, Mar. Geol. 132 (1996) 215-225.

[7] M.B. Cita, F. Aghib, S. Arosio, S. Folco, L. Sarto, E. Erba, A. Rizzi, Bacterial colonies and manganese micronodules related to fluid escape on the crest of the Mediterranean Ridge, Riv. Ital. Paleontol. Stratigr. 95 (1989) 315-336.

[8] C.B. Ramsey, S.W. Manning, M. Galimberti, Dating the volcanic eruption at Thera, Radiocarbon 46 (1) (2004) 325-344. 
[9] P.E. LaMoreaux, Worldwide environmental impacts from the eruption of Thera, Environ. Geol. 26 (3) (1995) 172-181.

[10] D.M. Pyle, The global impact of the Minoan eruption of Santorini, Greece, Environ. Geol. 30 (1/2) (1997) 59-61.

[11] J. Keller, W.B.F. Ryan, D. Ninkovich, R. Altherr, Explosive volcanic activity in the Mediterranean over the past 200,000 yr as recorded in deep-sea sediments, Geol. Soc. Amer. Bull. 89 (1978) 591-604.

[12] R.S.J. Sparks, S. Brazier, T.C. Huang, D. Muerdter, Sedimentology of the Minoan deep-sea tephra layer in the Aegean and Eastern Mediterranean, Mar. Geol. 54 (1983) 131-167.

[13] B. Narcisi, L. Vezzoli, Quaternary stratigraphy of distal tephra layers in the Mediterranean - an overview, Global Planet, Change 21 (1999) 31-50.

[14] F.W. McCoy, G. Heiken, Tsunami generated by the Late Bronze Age eruption of Thera (Santorini), Greece, Pure Appl. Geophys. 157 (2000) 1227-1256.

[15] K.A. Kastens, M.B. Cita, Tsunami-induced sediment transport in the abyssal Mediterranean Sea, Geol. Soc. Amer. Bull. 92 (1981) $845-857$.

[16] M.B. Cita, A. Camerlenghi, K.A. Kastens, F.W. McCoy, New findings of Bronze Age homogenites in the Ionian Sea-geodynamical implications for the Mediterranean, Mar. Geol. 55 (1984) 47-62.

[17] M.B. Cita, A. Camerlenghi, B. Rimoldi, Deep-sea tsunami deposits in the eastern Mediterranean: new evidence and depositional models, Sediment. Geol. 104 (1996) 155-173.

[18] W. Hieke, A thick Holocene homogenite from the Ionian Abyssal Plain (eastern Mediterranean), Mar. Geol. 55 (1984) 63-78.

[19] M.B. Cita, G. Aloisi, Deep-sea tsunami deposits triggered by the explosion of Santorini (3500 y BP), eastern Mediterranean, Sediment. Geol. 135 (2000) 181-203.

[20] W. Hieke, F. Werner, The Augias megaturbidite in the central Ionian Sea (central Mediterranean) and its relation to the Holocene Santorini event, Sediment. Geol. 135 (2000) 205-218.

[21] R.A. Jahnke, Geochemical impacts of waste disposal on the abyssal seafloor, J. Mar. Syst. 14 (1998) 355-375.

[22] T.S.R. Wilson, J. Thomson, Calcite dissolution accompanying early diagenesis in turbiditic deep ocean sediments, Geochim. Cosmochim. Acta 62 (1998) 2087-2096.

[23] M. Haeckel, J. van Beusekom, M.G. Wiesner, I. König, The impact of the 1991 Mount Pinatubo tephra fallout on the geochemical environment of the deep-sea sediments in the South China Sea, Earth Planet. Sci. Lett. 193 (2001) 151-166.

[24] D. Postma, Concentration of $\mathrm{Mn}$ and separation from $\mathrm{Fe}$ in sediments: 1 . Kinetics and stoichiometry of the reaction between birnessite and dissolved Fe(II) at 10 degrees C, Geochim. Cosmochim. Acta 49 (1985) 1023-1033.

[25] T.R.S. Wilson, J. Thomson, S. Colley, D.J. Hydes, N.C. Higgs, J. Sørensen, Early organic diagenesis: the significance of progressive subsurface oxidation fronts in pelagic sediments, Geochim. Cosmochim. Acta 49 (1985) 811-822.

[26] J. Thomson, N.C. Higgs, I.W. Croudace, S. Colley, D.J. Hydes, Redox zonation of elements at an oxic/post-oxic boundary in deep-sea sediments, Geochim. Cosmochim. Acta 57 (1993) $579-595$.

[27] A. Mucci, H.M. Edenborn, Influence of an organic-poor landslide deposit on the early diagenesis of iron and manganese in a coastal marine sediment, Geochim. Cosmochim. Acta 56 (1992) 3909-3921.

[28] B. Deflandre, A. Mucci, J.-P. Gagné, C. Guignard, B. Sundby, Early diagenetic processes in coastal marine sediments disturbed by a catastrophic sedimentation event, Geochim. Cosmochim. Acta 66 (2002) 2547-2558.

[29] A. Mucci, B. Boudreau, C. Guignard, Diagenetic mobility of trace elements in sediments covered by a flash flood deposit: Mn, Fe and As, Appl. Geochem. 18 (2003) 1011-1026.

[30] M. Jung, J. Ilmberger, A. Mangini, K.C. Emeis, Why some Mediterranean sapropels survived burn-down (and others did not), Mar. Geol. 141 (1997) 51-60.

[31] M. Totland, I. Jarvis, K.E. Jarvis, An assessment of dissolution techniques for the analysis of geological samples by plasma spectroscopy, Chem. Geol. 95 (1992) 35-62.

[32] J.H.B. van Os, J.J. Middelburg, G.J. de Lange, Possible diagenetic mobilization of barium in sapropelic sediment from the eastern Mediterranean, Mar. Geol. 100 (1991) 125-136.

[33] D. Mercone, J. Thomson, I.W. Croudace, G. Siani, M. Paterne, S. Troelstra, Duration of S1, the most recent sapropel in the eastern Mediterranean Sea, as indicated by AMS radiocarbon and geochemical evidence, Paleoceanography 15 (2000) 336-347.

[34] C.P. Slomp, J. Thomson, G.J. de Lange, Enhanced regeneration of phosphorous during formation of the most recent eastern Mediterranean sapropel (S1), Geochim. Cosmochim. Acta 66 (2002) $1171-1184$.

[35] J. Thomson, D. Crudeli, G.J. de Lange, C.P. Slomp, E. Erba, C. Corselli, Florisphaera profunda and the origin and diagenesis of carbonate phases in eastern Mediterranean sapropel units, Paleoceanography 9 (2004) PA3003, doi:10.1029/2003PA000976.

[36] A. Reitz, G.J. de Lange, Enhanced Sr-rich aragonite in eastern Mediterranean sapropel (S1): diagenetic versus detrital/biogenic origin, Palaeogeogr. Palaeoclimatol. Palaeoecol. (in press).

[37] M. Stuiver, T.F. Braziunas, Modeling atmospheric ${ }^{14} \mathrm{C}$ influences and ${ }^{14} \mathrm{C}$ ages of marine samples to $10,000 \mathrm{BC}$, Radiocarbon 35 (1993) 137-189.

[38] P. Schmid, C. Peltz, V.M.F. Hammer, E. Halwax, T. Ntaflos, P. Nagl, M. Bichler, Separation and Analysis of Theran Volcanic Glass by INAA, XRF and EPMA, Mikrochim. Acta 133 (2000) $143-149$.

[39] C. Peltz, M. Bichler, Classification of archaeologically stratified pumice by INAA, J. Radioanal. Nucl. Chem. 248 (2001) 81-87.

[40] C.U. Hammer, G. Kurat, P. Hoppe, W. Grum, H.B. Clausen, Thera eruption date 1645 BC confirmed by new ice core data?, Paper Presented at the SCIEM 2000-EuroConference, SCIEM, Vienna, 2003.

[41] S. Saminger, C. Peltz, M. Bichler, South Aegean volcanic glass: separation and analysis by INAA and EPMA, J. Radioanal. Nucl. Chem. 245 (2000) 375-383.

[42] N.J.G. Pearce, W.J. Eastwood, J.A. Westgate, W.T. Perkins, Trace-element composition of single glass shards in distal Minoan tephra from SW Turkey, J. Geol. Soc. Lond. 159 (2002) 545-556.

[43] N.J.G. Pearce, J.A. Westgate, W.T. Perkins, S.T. Preece, The application of ICP-MS methods to tephrochronological problems, Appl. Geochem. 19 (2004) 289-322.

[44] F.W. McCoy, The upper Thera (Minoan) ash in deep-sea sediments: distribution and comparison with other ash layers, in: C. Dumas (Ed.), Thera and the Aegean World, Proceedings 2nd International Scientific Congress on the Volcano Thera, Greece, vol. 2, 1980, pp. 57-78.

[45] F.W. McCoy, Areal distribution, redeposition and mixing of tephra within deep-sea sediments of the Eastern Mediterranean Sea, in: S. Self, R.S.J. Sparks (Eds.), Tephra Studies, Nato Advanced Study Institutes Series C, vol. 75, Reidel, Dordrecht, 1981, pp. $245-254$. 
[46] T.R.S. Wilson, J. Thomson, D.J. Hydes, S. Colley, F. Culkin, J. Sørensen, Oxidation fronts in pelagic sediments: diagenetic formation of metal-rich layers, Science 232 (1986) 972-975.

[47] D. Mercone, J. Thomson, R.H. Abu-Zied, I.W. Croudace, E.J. Rohling, High-resolution geochemical and micropalaeontological profiling of the most recent eastern Mediterranean sapropel, Mar. Geol. 177 (2001) 25-44.

[48] J. Thomson, N.C. Higgs, I. Jarvis, D.J. Hydes, S. Colley, T.R.S. Wilson, The behaviour of manganese in Atlantic carbonate sediments, Geochim. Cosmochim. Acta 50 (1986) 1807-1818.

[49] G.B. Shimmield, N.B. Price, The behaviour of molybdenum and manganese during early sediment diagenesis-offshore Baja California, Mexico, Mar. Chem. 19 (1986) 261-280.
[50] S.R. Troelstra, G.M. Ganssen, K. van der Borg, A.F.M. de Jong, A late Quaternary stratigraphic framework for eastern Mediterranean sapropel S1 based on AMS C-14 dates and stable oxygen isotopes, Radiocarbon 33 (1991) 15-21.

[51] A. Rutten, G.J. de Lange, P. Ziveri, J. Thomson, P.J.M. van Santvoort, S. Colley, C. Corselli, Recent terrestrial and carbonate fluxes in the pelagic 25 eastern Mediterranean; a comparison between sediment trap and surface sediment, Palaeogeogr. Palaeoclimatol. Palaeoecol. 158 (2000) 197-213.

[52] M. Rebesco, B. Della Vedova, L. Cernobori, G. Aloisi, Acoustic facies of Holocene megaturbidites in the Eastern Mediterranean, Sediment. Geol. 135 (2000) 65-74. 